\title{
Description of two new species of Plesiopelma (Araneae, Theraphosidae, Theraphosinae) from Argentina
}

\author{
Nelson Ferretti \& Jorge Barneche
}

Centro de Estudios Parasitológicos y de Vectores CEPAVE (CCT- CONICET- La Plata) (UNLP), Calle 2 n584, La Plata, Argentina. (nferretti@conicet.gov.ar; grammostola15@hotmail.com)

\begin{abstract}
Two new species of Plesiopelma Pocock, 1901 from northern Argentina are described and diagnosed based on males and habitat descriptions are presented. Males of Plesiopelma paganoi sp. nov. differ from most of species by the absence of spiniform setae on the retrolateral face of cymbium, aspect of the palpal bulb. Plesiopelma aspidosperma sp. nov. differs from most species of the genus by the presence of spiniform setae on the retrolateral face of cymbium and it can be distinguished from P. myodes Pocock, 1901, P. longisternale (Schiapelli \& Gerschman, 1942 ) and $P$. rectimanum (Mello-Leitão, 1923) by the separated palpal bulb keels and basal nodule of metatarsus I very developed. It differs from P. minense (Mello-Leitão, 1943) by the shape of the palpal bulb and basal nodule on metatarsus I well developed. Specimens were captured in Salta province, Argentina, inhabiting high cloud forests of Yungas eco-region.
\end{abstract}

KEYWORDS. Taxonomy, spiders, natural history, Neotropical, Yungas.

RESUMEN. Descripción de dos nuevas especies de Plesiopelma (Araneae, Theraphosidae, Theraphosinae) de Argentina. Dos nuevas especies de Plesiopelma Pocock, 1901 del norte de Argentina son diferenciadas y se describen en base a ejemplares machos y se presentan descripciones de los ambientes. Machos de Plesiopelma paganoi sp. nov. difieren de la mayoría de las especies por la ausencia de setas espiniformes en la cara retrolateral del cymbium, por la forma del órgano palpar. Plesiopelma aspidosperma sp. nov. difiere del resto de las especies por la presencia de setas espiniformes en la cara retrolateral del cymbium y se distingue de P. myodes Pocock, 1901, P. longisternale (Schiapelli \& Gerschman, 1942) y P. rectimanum (Mello-Leitão, 1923) por las quillas del bulbo separadas y el nódulo basal del metatarso I muy desarrollado. Se diferencia de $P$. minense (Mello-Leitão, 1943) por la forma del órgano palpar y el nódulo basal del metatarso I desarrollado. Los especímenes se capturaron en la provincia de Salta, Argentina, habitando nuboselvas de altura en la eco-región de Yungas.

PALABRAS-CLAVE. Taxonomía, arañas, historia natural, Neotropical, Yungas.

Theraphosidae is a family of spiders comprising the largest known specimens in the world, with 950 described species in 124 genera constituting the most speciose family of the Mygalomorphae (Platnick, 2013). They are distributed throughout all tropical and many subtropical areas, mainly in Neotropical, Ethiopian, Oriental and Australian regions, with a few species in Europe (Miglio et al., 2013). Most of the known species inhabit the Neotropics and are included in the Theraphosinae, endemic to this region. Very little is known about the biology of the Theraphosidae and due to the homogeneity of theraphosinae morphology and the scarcity of taxonomic characters, its taxonomy is in a chaotic state (RAven, 1990, Pérez-Miles et al., 1996; BERTANI, 2000). Despite the progress in the taxonomy of Theraphosidae in the last twenty years, much is yet to be done (Bertani et al., 2012; Miglio et al., 2013).

The genus Plesiopelma Pocock, 1901 comprises nine species recorded in Argentina, Brazil, Paraguay, Uruguay and Venezuela (Platnick, 2013). The type species, Plesiopelma myodes Pocock, 1901 was described by original designation and monotypy based on a male specimen from Uruguay. PIZA (1976) described Plesiopelma imperatrix based on a female from Brazil, but with unknown locality. This species exhibit some diagnostic characters, such as presence of urticating hairs type I, femur III incrassate and spermathecae with one single receptacle that belong to other theraphosid genus (PÉREZ-Miles et al. 1996, Nagahama, unpublished data) and will be not considered for comparisons in this study. PÉREZMiLes et al. (1996) considered Plesiopelma as a senior synonym of Ceropelma Mello-Leitão, 1923, containing at that time five species: C. flavohirtum (Simon, 1889), C. semiaurantiacum (Simon, 1897), C. insularis MelloLeitão, 1923, C. longisternalis Schiapelli \& Gerschman, 1942 and C. gertschi Capocariacco, 1955. Plesiopelma flavohirtum was transferred to Catanduba by ҮАмАмото et al. (2012). Plesiopelma semiaurantiacum was described by Simon (1897) based on a male and female from Colonia Risso, Paraguay. Then, Mello-Leitão (1923a) described Plesiopelma insulare based on a male from Ilha de Alcatrazes, state of São Paulo, Brazil. In this same work, the author described Hapalopus rectimanum, later transferred to Plesiopelma by PÉREZMiLes et al. (1996). Plesiopelma longisternale was established by Schiapelli \& Gerschman (1942) based on a male specimen from Campo Gallo, Santiago del Estero Province, Argentina. This is the only species recorded for Argentina (SCHIAPELli \& GerSCHMAN, 1942; Platnick, 2013) with a wide distribution, comprising the provinces of Buenos Aires, Catamarca, Chaco, Córdoba, Corrientes, Entre Ríos, La Pampa, La Rioja, Mendoza and Santiago del Estero. Later, CAPOCARIACCO (1955) described Plesiopelma gertschi from a female of Barcelona, Anzoátegui, Venezuela, significantly expanding the geographical distribution of the genus. Yамамото et al. (2007) transferred Tmesiphantes physopus Mello-Leitão, 1926 and T. minensis MelloLeitão, 1943 to Plesiopelma. Plesiopelma physopus was 
described by Mello-Leitão (1926) based on a male from Campina Grande, state of Paraíba, Brazil, but the type material is probably lost (ҮАмамото et al., 2007). Finally, Nagahama (unpublished data presented a revision and cladistic analysis of the genus Plesiopelma for his M.Sc. thesis dissertation. Unfortunately, according to the International Code of Zoological Nomenclature (articles 8 and 9 , chapter $3,4^{\text {th }}$ edition) any proposal of nomenclatural changes and/or designation of types or type localities on a dissertation work are not valid as a publication (ICZN, 1999). However, the contribution of NagaHAma (unpublished data) allowed us to make comparisons of our material with the description and illustrations of the taxa treated in its work.

In a recent survey carried out in northern Salta province, Argentina, two new species of Plesiopelma were discovered and are herein described, diagnosed and some aspects on natural history are presented.

\section{MATERIAL AND METHODS}

The following abbreviations are utilized: ALE $=$ anterior lateral eyes; $\mathrm{AME}=$ anterior median eyes; $\mathrm{BN}=$ basal nodule; $\mathrm{D}=$ dorsal $\mathrm{P}=$ prolateral $\mathrm{PB}=$ prolateral branch of tibial apophysis; PI = prolateral inferior keel; PLE $=$ posterior lateral eyes; PLS = posterior lateral spinnerets; $\mathrm{PME}=$ posterior median eyes; $\mathrm{PMS}=$ posterior median spinnerets; PS $=$ prolateral superior keel; $\mathrm{R}=$ retrolateral; $\mathrm{RB}=$ retrolateral branch of tibial apophysis. Female genitalia was dissected and cleared in concentrated lactic acid for 60-120 minutes to study the shape of spermathecae. All measurements are given in millimeters and were made with digital dial calipers with an error of $0.01 \mathrm{~mm}$, rounded up to one significant decimal where appropriate and an Olympus stereoscopic microscope equipped with a calibrated ocular micrometer scale. Photographs of preserved material were taken with a SONY Hx200v. The material studied are deposited in the arachnological collection of the Museo de La Plata (MLP, Luis Pereira), Buenos Aires, Argentina and Laboratorio de Zoología de Invertebrados II, Universidad Nacional del Sur (LZI, Nelson Ferretti), Bahía Blanca, Argentina. Spine notation follows Petrunkevitch (1925). Male palpal bulb keel terminology follows BerTani (2000). Urticating setae terminology follows Cooke et al. (1972).

\section{RESULTS AND DISCUSSION}

\section{Plesiopelma Pocock, 1901}

Plesiopelma Pocock, 1901:553; Petrunkevich, 1911:85 (catalog); PÉREZ-Miles et al., 1996:55 (removed from the synonymy of Citharacanthus).

Citharacanthus Pocock, 1901:551; PÉREZ-Miles et al., 1996:46 (in part).

Dryptopelma Simon, 1889:402 (in part).
Eurypelma C. L. KocH, 1850:70 (in part); RoEwer, 1942:240 (in part); BRIGNOLI, 1983:137 (in part).

Ceropelma Mello-Leitão, 1923b:175; Pérez-Miles et al., 1996:55 (synonymized with Plesiopelma).

Type species: P. myodes Pocock, 1901, defined by monotypy.

Diagnosis. Differs from other theraphosids, except from some species of Homoeomma, by the presence of long convergent setae at central dorsal abdomen. Males differ from the other genera of Theraphosinae in the presence of a small subapical tooth on the bulb, absent in $P$. paganoi sp. nov. and P. aspidosperma sp. nov., in combination with a retrolateral basal nodule on metatarsus I (less or well developed). Palpal bulb with rounded body, prolateral superior and inferior keels well developed, parallel, close or separated to each other. Females differ by the spiral-shaped spermathecae with presence of granules.

Other material examined. Plesiopelma longisternale (Schiapelli \& Gerschman 1942), 30े, X.2009, Sierra de la Ventana, Buenos Aires, Argentina ( $37^{\circ} 08^{\prime} 13^{\prime \prime}$ S, $\left.61^{\circ} 57^{\prime} 25^{\prime \prime} \mathrm{W}\right)$, N. Ferretti \& S. Copperi leg. (LZI 0074, 0075, 0076); $\partial^{\lambda}$, V.2006, Las Gaviotas, Caleu Caleu, La Pampa, Argentina ( $\left.38^{\circ} 45^{\prime} \mathrm{S}, 63^{\circ} 45^{\prime} \mathrm{W}\right)$, R. Tizón leg. (LZI 0082).

\section{Plesiopelma paganoi sp. nov.}

(Figs 1-6; Tab. I)

Type material. Holotype $\widehat{\alpha}$, Argentina, Salta, Department of San Martín, at about $14 \mathrm{~km}$ western of Aguaray locality ( $22^{\circ} 17^{\prime} 14.11^{\prime \prime S}$ $\left.63^{\circ} 50^{\prime} 11.64^{\prime \prime} \mathrm{W}\right)$, collected as juvenile on 24.VII.2011, molted to adult 22.IX.2011, L. Pagano leg. (MLP 19190). Paratype $\widehat{\partial}$, Argentina, Salta, San Martín, at about $20 \mathrm{~km}$ western of Tartagal locality $\left(22^{\circ} 32^{\prime} 00.34^{\prime \prime} \mathrm{S}, 63^{\circ} 59^{\prime} 39.09^{\prime} \mathrm{W}\right)$ collected as juvenile on 2.XII.2011, J. Barneche leg. (MLP 19191).

Etymology. The specific name is a patronym in honor of Luis G. Pagano, Argentinean ornithologist who participated in the collection of this new species.

Diagnosis. Plesiopelma paganoi sp. nov. differs from most of Plesiopelma species, except from $P$. insulare, by the high number of labial and maxillary cuspules (more than 130) and absence of spiniform setae on the retrolateral face of cymbium. It differs from $P$. insulare by the aspect of the palpal bulb, which presents a slender shape, shorter and strongly curved embolus with tooth absent.

Tab. I. Plesiopelma paganoi sp. nov., length of leg and palpal segments of male.

\begin{tabular}{lccccc}
\hline & I & II & III & IV & Palp \\
\hline Femur & 10.9 & 11.0 & 9.1 & 11.8 & 7.1 \\
Patella & 5.8 & 6.2 & 4.9 & 5.5 & 4.4 \\
Tibia & 8.3 & 8.4 & 6.8 & 7.8 & 6.0 \\
Metatarsus & 9.4 & 7.9 & 7.8 & 10.6 & - \\
Tarsus & 5.9 & 5.4 & 5.3 & 6.4 & 2.4 \\
Total & 40.3 & 38.9 & 33.9 & 42.1 & 19.9 \\
\hline
\end{tabular}




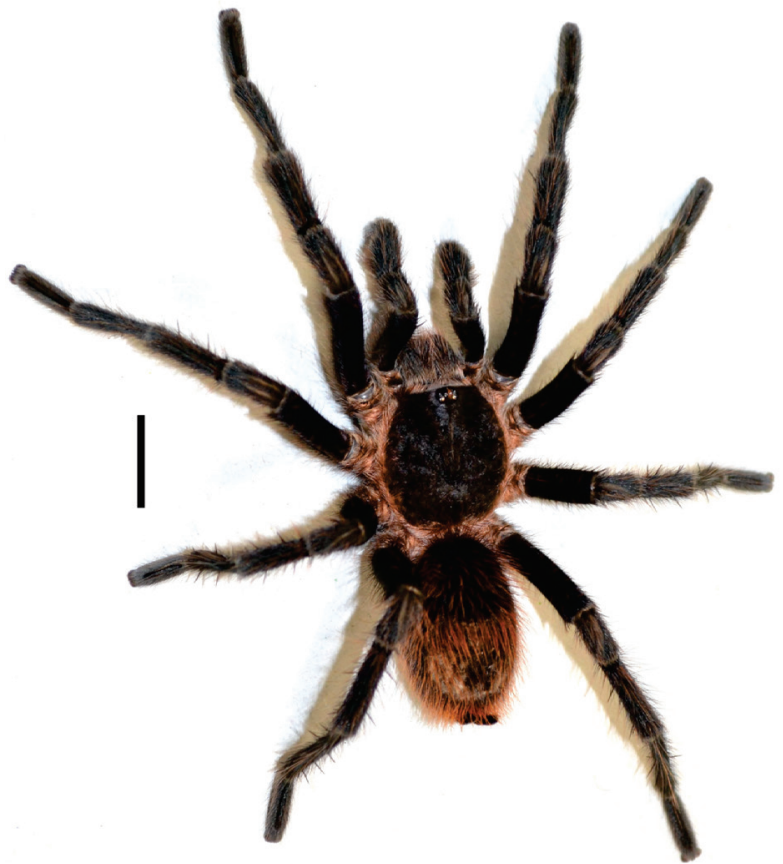

Fig. 1. Plesiopelma paganoi sp. nov., male paratype (MLP 19191), habitus. Scale: $1 \mathrm{~cm}$.

Description. Color in vivo (male paratype, MLP 19191): carapace and legs dorsally black with whitish setae on carapace border, coxae and trochanters. Abdomen dorsally black with reddish setae (Fig. 1). Male holotype (MLP 19190): specimen lost most of urticating hairs, abdomen dorsal area is nearly bare, some urticating setae type III were observed. Total length (not including chelicerae or spinnerets) 29.1. Cephalothorax 14.9 long (Fig. 2), 12.1 wide. Abdomen 15.0 long, 7.3 wide. Spinnerets: PMS, 1.1 long, 0.4 wide; PLS, 1.5 basal, 2 middle, 2.4 domed distal. Eyes: tubercle length 1.5, width 1.8. Clypeus narrow, 0.6. Anterior eyes row procurved, posterior row recurved. Eyes sizes and interdistances: AME 0.29, ALE 0.44, PME 0.22, PLE 0.36, AME - AME 0.34, AME - ALE 0.29, PME - PME 0.77, PME - PLE 0.14, ALE - PLE 0.28. Fovea transverse, deep procurved, 1.9 wide. Labium length 2.0, width 1.6, with 137 cuspules. Maxillae each with 187 cuspules spread over internal face. Sternum: length 6.2, width 3.6. Chelicerae with 10 large teeth on promargin, group of 21 smaller basal teeth behind promarginal line. Length of legs and palpal segments in Tab. I. Tarsi I - IV densely scopulate, scopula I - III entire, IV divided by lines of setae increasing in width from apical (3 - 4 setae) to basal (10 - 12 setae). Metatarsi I fully scopulate, II 2/3 apical scopulate, III 1/2 apical scopulate, IV 1/4 apical scopulate. Spination: femora of I and IV, 1 D; femora II and III and patellae of I - IV and palp, 0. Tibiae: palp 2 P; I 1 V, 1 P, 1 R; II 2, $1-1$ P; III $1-1-2 \mathrm{~V}, 1-1 \mathrm{P}$, $1-1 \mathrm{R}$; IV $1-2 \mathrm{~V}, 1-1 \mathrm{R}, 1-1 \mathrm{P}$. Metatarsi: I $1 \mathrm{~V}$; II $1 \mathrm{~V}$; III $1-1-1 \mathrm{~V}, 1-1-2 \mathrm{P}, 1-1 \mathrm{R}$; IV $1-1-1$ $\mathrm{V}, 1-1-1 \mathrm{P}, 1-1 \mathrm{R}$. Tarsi I - IV, palps 0 . Absence of spiniform setae on the retrolateral face of cymbium and palpal tibia (Fig. 3). Tibia I with ventral apophysis formed by two branches (Fig. 4): prolateral smaller, with a basal megaspine and 9 short spines on inner face; retrolateral larger with a subapical megaspine and 12 short spines on inner face, these arranged in two rows. Metatarsus of leg I with basal rounded nodule not well developed (Fig. 4) and flexes between both branches of tibial apophysis, touching their medial portion. Male palpal bulb with main body elongated, narrowed, with well-developed PI and PS, close and parallel to each other (Figs 5, 6). Embolus short with strong and pronounced curvature and tip thick. Subapical tooth en embolus absent.

Distribution. Northern Salta province, Argentina, next to the southern limit of Bolivia (Fig. 17).

Habitat description. Plesiopelma paganoi sp. nov. was found only in high cloud forest in the Yungas eco-region. This region comprises one of the most diverse ecosystems in Argentina (CABRERA, 1976; CABrera \& Willink, 1980). This high cloud forest represents less than $2 \%$ of the Argentinean territory but contains even $50 \%$ of the known biodiversity. The vegetation is distinguished by floors or stripes of well differentiate physiognomic characteristics. A juvenile specimen was found at the piedmont jungle inhabiting in small crevices under decomposing logs (Fig. 7), a

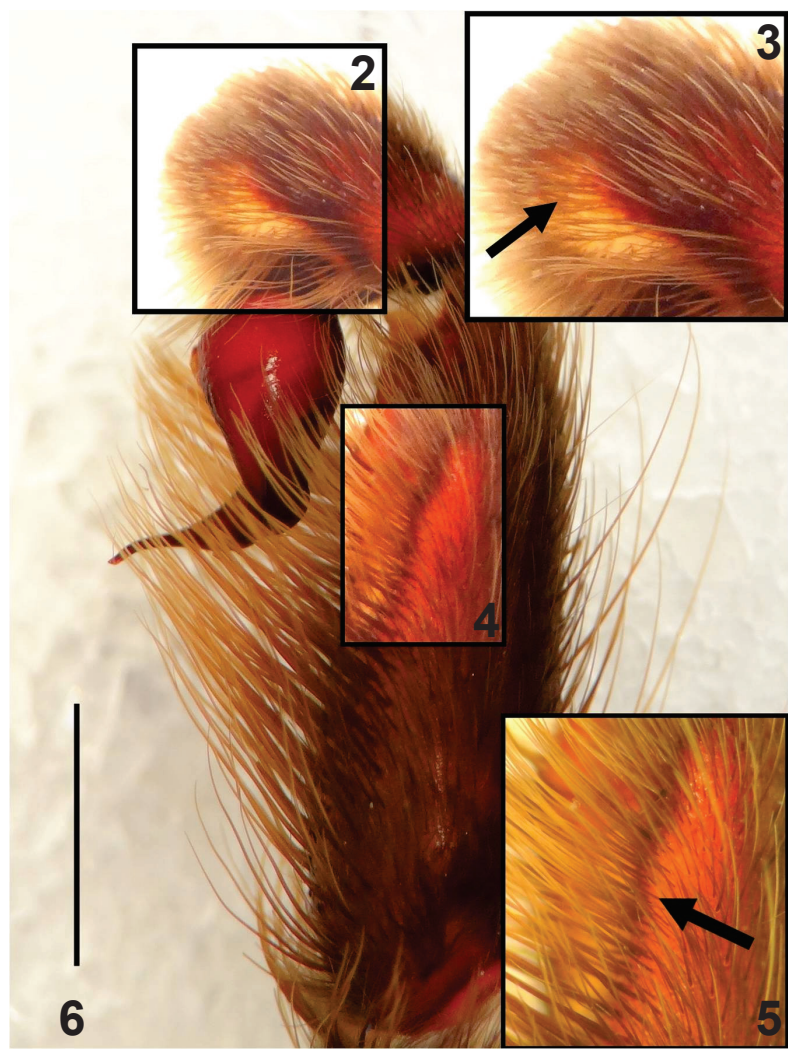

Figs 2-6. Plesiopelma paganoi sp. nov., male holotype (MLP 19190): 2, carapace, dorsal; 3, palp, retrolateral (arrows show the absence of spiniform setae on tibia and cymbium); 4, tibial apophyses, ventral; 5, 6 , copulatory bulb prolateral and retrolateral respectively. Scale: $1 \mathrm{~mm}$. 


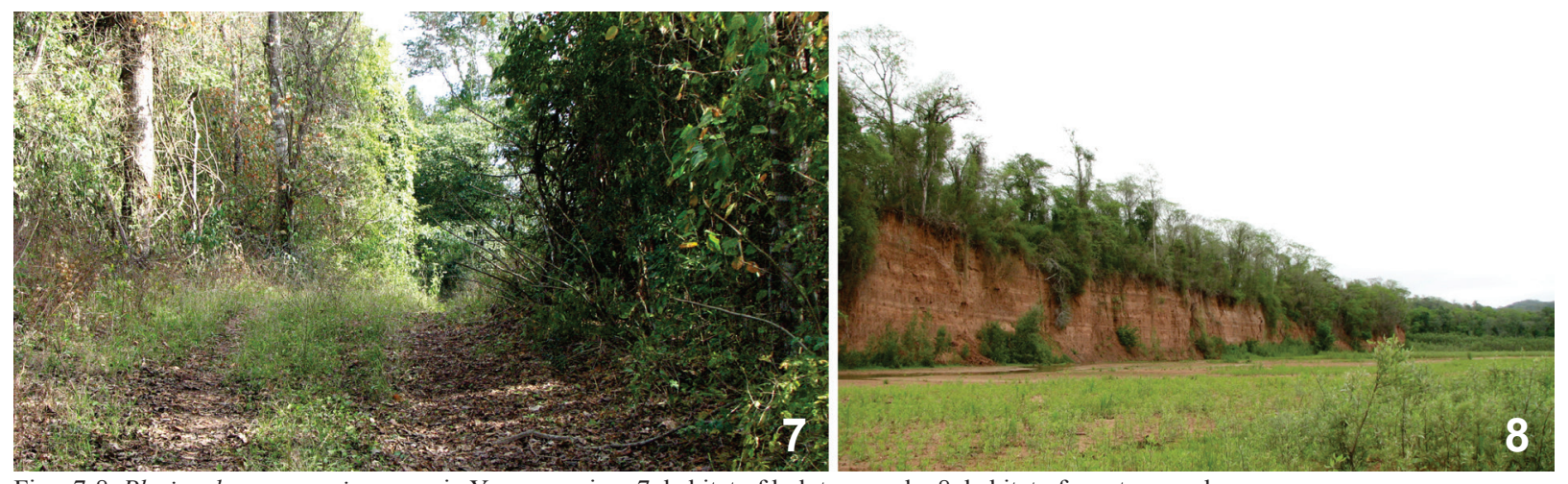

Figs. 7-8. Plesiopelma paganoi sp. nov. in Yungas region: 7, habitat of holotype male; 8, habitat of paratype male.

microhabitat shared with specimens of an undetermined species of Acanthoscurria (Jorge Barneche, pers. obs.). The other juvenile was captured walking at about 11-12 p.m. between shrubs next to a path and a dry river (Fig. 8). In this habitat, also specimens of Grammostola sp., Melloleitaoina crassifemur Gerschman \& Schiapelli, 1960 (Theraphosidae) and Diplura sp. (Dipluridae) can be found (Jorge Barneche, pers. obs.). The piedmont jungle occupies the altitudinal level of about 400 and 700 m.a.s.l. represented by valleys, plains and hills. It has been proposed that this jungle constitutes a "biogeographic relict" due to ancient connections with other South American seasonal forests, such as Caatinga in Brazil (Prado, 2000; Morrone, 2006). Moreover, this area harbors a high percentage of exclusive species (about 30\% of the total species) and some of the characteristics trees species are Calycophyllum multiflorum (Palo blanco) and Phyllostilon rhamnoides (Palo amarillo).

\section{Plesiopelma aspidosperma sp. nov. (Figs 9-15; Tab. II)}

Type material. Holotype ${ }^{\lambda}$, Argentina, Salta, Department of Rivadavia, at about $28 \mathrm{~km}$ eastern of Fuente de Aguirre locality

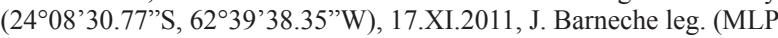
19192).

Etymology. The species is named to the genera of an emblematic tree from the eastern Salta province, Argentina, Aspidosperma, known as "quebracho blanco" in Spanish. The characteristic species in the area is Aspidosperma quebracho-blanco (Schltr.) Lyons. It is medically important due to an extract obtained from the bark known as "yohimbe", used around the world to treat asthma, lung disorders, coughs, fevers and other conditions. The specimen of $P$. aspidosperma was located near to a group of trees of this species.

Diagnosis. Plesiopelma aspidosperma sp. nov. differs from $P$. insulare by spiniform setae on the retrolateral face of cymbium. It can be distinguished from $P$. myodes, $P$. longisternale and $P$. rectimanum by the separated palpal bulb keels and basal nodule of metatarsus I very developed. It differs from $P$. minense by embolus tooth absent, embolus slender and curved and basal nodule on metatarsus I more developed.

Description. Color in vivo (male holotype, MLP 19192): carapace and legs dorsally dark with pinkish setae on carapace border, coxae and trochanters. Abdomen dorsally black with few reddish setae and orange setae on spinnerets (Fig. 9). Urticating setae type III and IV present. Total length (not including chelicerae or spinnerets) 16.4. Cephalothorax 8.4 long (Fig. 10), 6.1 wide. Abdomen 8.0 long, 3.6 wide. Spinnerets: PMS, 0.4 long, 0.2 wide; PLS, 0.7 basal, 1.1 middle, 1.3 domed distal. Eyes: tubercle length 0.7, width 0.9 . Clypeus narrow, 0.1. Anterior eyes row procurved, posterior row recurved. Eyes sizes and inter-distances: AME 0.19, ALE 0.13, PME 0.12, PLE 0.12, AME - AME 0.16, AME - ALE 0.08, PME - PME 0.44, PME - PLE 0.03, ALE - PLE 0.12. Fovea transverse, deep, highly procurved, 0.8 wide. Labium length 0.9 , width 0.7 , with 44 cuspules. Maxillae each with 77 cuspules spread over internal face. Sternum (Fig. 11): length 3.4, width 1.9. Chelicerae with 10 large teeth on promargin, group of 13 smaller basal teeth behind promarginal line. Length of legs and palpal segments in Tab. II. Tarsi I - IV densely scopulate, scopula I entire, II - III divided by narrow line of setae, IV divided by wide line of 4 setae. Metatarsi I 3/4 distal scopulate, II 2/3 apical scopulate, III $1 / 2$ apical scopulate, IV $1 / 3$ apical scopulate. Spination: femora of I, III and palp, 1 D; femora II and IV and patellae of I - IV and palp, 0. Tibiae: palp $2-1 \mathrm{D}$; I $2-1-2 \mathrm{~V}, 1-1 \mathrm{P}$; II $1-2-2$ V, $1-1 \mathrm{R}$; III $1-2-2 \mathrm{~V}, 1-1 \mathrm{R}, 1 \mathrm{P}$; IV $2-2-2 \mathrm{~V}$, $1-1$ P. Metatarsi: I 1 V; II $1-1 \mathrm{~V}$; III $1-1-3 \mathrm{~V}, 1-1$

Tab. II. Plesiopelma aspidosperma sp. nov., length of leg and palpal segments of male.

\begin{tabular}{lccccc}
\hline & I & II & III & IV & Palp \\
\hline Femur & 5.8 & 5.1 & 4.5 & 5.4 & 3.5 \\
Patella & 3.6 & 2.7 & 2.1 & 2.7 & 2.4 \\
Tibia & 4.7 & 4.4 & 3.9 & 4.9 & 3.1 \\
Metatarsus & 4.2 & 4.5 & 3.5 & 5.5 & - \\
Tarsus & 3.6 & 2.8 & 3.0 & 3.9 & 1.2 \\
Total & 21.9 & 19.5 & 17.0 & 22.4 & 10.2 \\
\hline
\end{tabular}




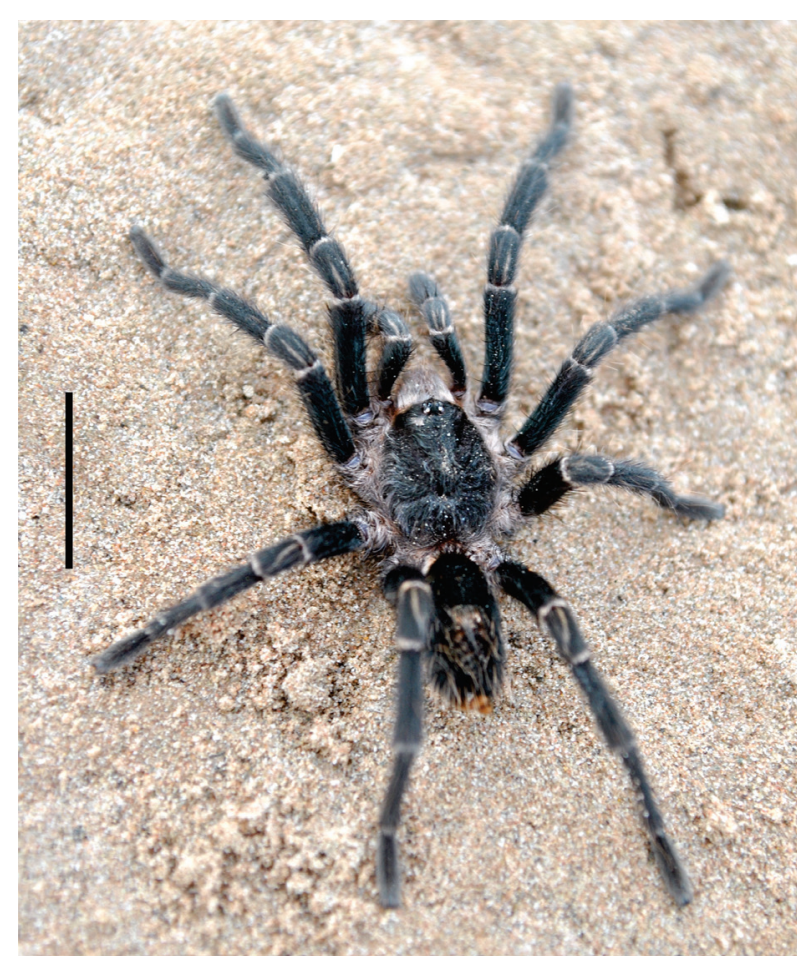

Fig. 9. Plesiopelma aspidosperma sp. nov., holotype male (MLP 19192), habitus. Scale: $1 \mathrm{~cm}$.

P, 1 R; IV $1-1-1-1-2$ V, $1-1$ P, $1-1$ R. Tarsi I $\mathrm{IV}$, palps 0 . Retrolateral face of palp tibia with a group of thickened setae. Retrolateral face of cymbium bearing spiniform setae (Fig. 12). Character used by FuKusHIMA et al. (2005) and FuKushima et al. (2008) and shared by Cyriocosmus elegans. Tibia I with ventral apophysis formed by two branches (Fig. 13): prolateral smaller, with a basal megaspine on inner face; retrolateral larger with a subapical megaspine, one smaller apical spine and 8 short spines on inner face, these arranged in two rows. Metatarsus of leg I with basal rounded nodule well developed (Fig. 13) and flexes between both branches of tibial apophysis, touching their medial portion. Male palpal bulb piriform, tapering abruptly, with well developed PS and less developed PI, not parallel to each other (Figs 14, 15). Noticeably constriction between the bulb body and embolus. Embolus very long (almost half of the total bulb length) and slender. Subapical tooth on embolus absent.

Distribution. Known only from the type locality, in western Salta province, Argentina (Fig. 17).

Habitat description. Plesiopelma aspidosperma sp. nov. was found only in the Semiarid Chaco ecoregion at eastern Salta province. In Argentina, this region extends in the provinces of Formosa, Chaco, Santiago del Estero, northern Córdoba and the oriental portion of Salta. The topography comprises plains, mountains and forests, becoming more arid from East to West. The climate is temperate and subtropical with a mean annual temperature of $22^{\circ} \mathrm{C}$ and means annual precipitations of about $500-700 \mathrm{~mm}$ (NAUMANN, 2006). The jungles are dominated by xeric vegetation (GIMÉnEZ \& MoGLIA, 2003). The characteristic vegetation corresponds to
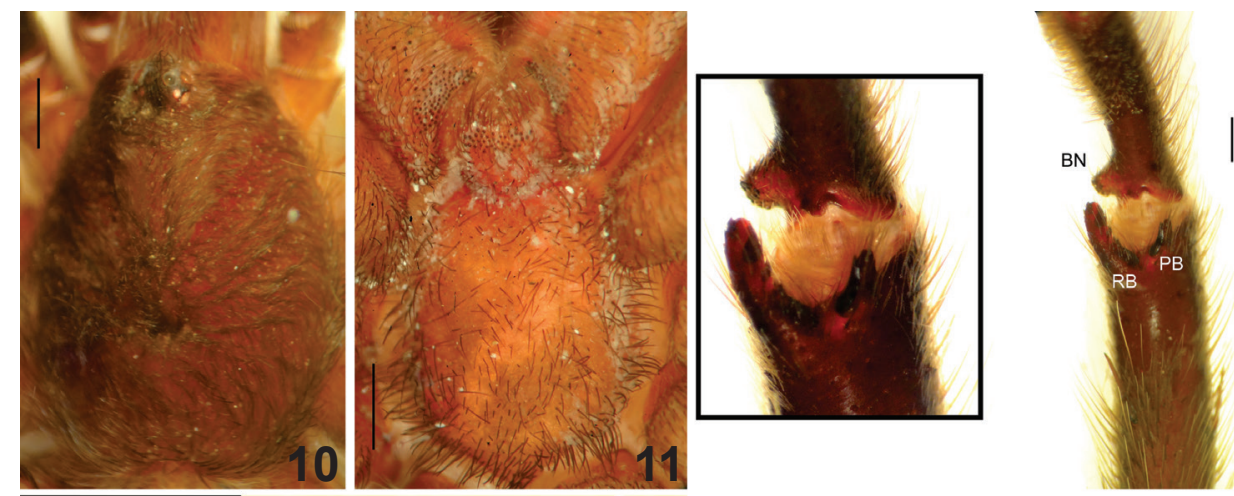

13
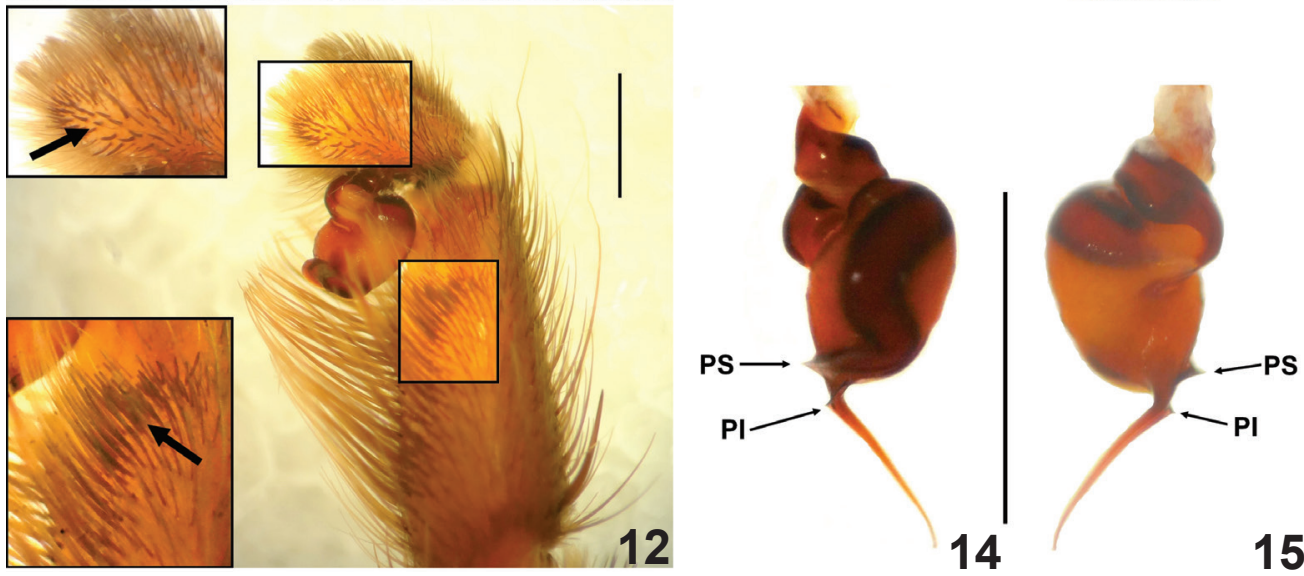

Figs. 10-15. Plesiopelma aspidosperma sp. nov., male holotype (MLP 19192): 10, carapace, dorsal; 11, sternum, ventral; 12, palp, retrolateral (arrows show the spiniform setae on tibia and cymbium); 13, tibial apophyses, ventral; 14, 15, copulatory bulb prolateral and retrolateral respectively. Scale: $1 \mathrm{~mm}$. 


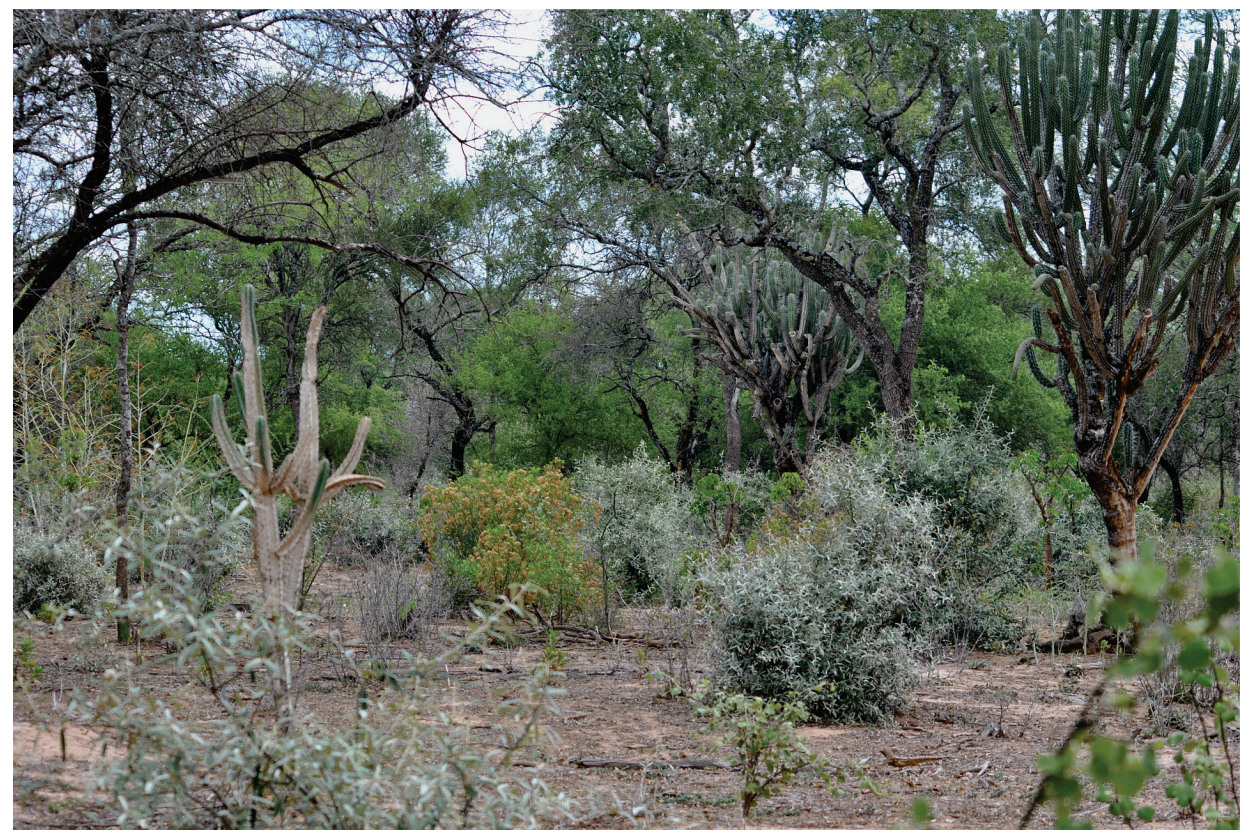

Fig. 16. Plesiopelma aspidosperma sp. nov. in semidry Chaco region, habitat of holotype male.

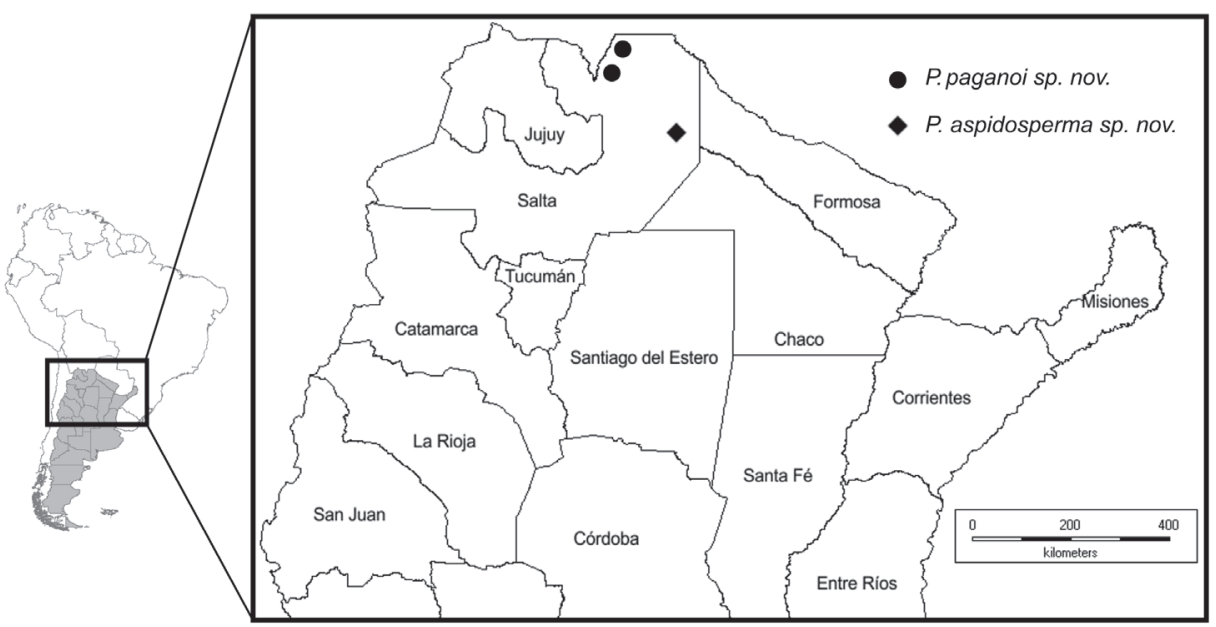

Fig. 17. Distribution map of Plesiopelma new species.

forests of Schinopsis lorentzii as dominant species together with Aspidosperma quebracho-blanco. Also, other tree species such as Zizyphus mistol, Prosopis alba, Prosopis nigra, Celtis tala, Geoffroea decorticans and Cercidium praecox are present (NAUMANN, 2006). Some of the characteristics shrubs that can be found in this area comprise: Mimosa detinens, Condalia microphylla, Maytenus spinosa, Atamisquea emarginata, Acacia furcatispina and Celtis chichape. Some specimens of Opuntia quimilo and Stetsonia coryne are present in this area (NAUMANN, 2006). The adult male of $P$. aspidosperma was found walking at about 7-8 p.m. in a sandy path, surrounded by Stetsonia coryne "cardones" and Aspidosperma quebracho-blanco (Fig. 16). In this habitat, also specimens of Grammostola sp., Acanthoscurria sp. (Theraphosidae) and Idiops clarus (Mello-Leitão, 1946) (Idiopidae) can be found (Jorge Barneche, pers. obs.).
Acknowledgements. Authors thank the Consejo Nacional de Investigaciones Científicas y Técnicas (CONICET); Nelson Ferretti is supported by a posdoctoral fellowship. Thanks to Alda González (CEPAVE, CCT-CONICET, La Plata, Argentina) for their constant support, Florencia Fortini for her valuable comments on the manuscript and Gabriel Pompozzi for taking some of the pictures.

\section{REFERENCES}

Bertani, R. 2000. Male palpal bulbs and homologous features in Theraphosinae, (Araneae, Theraphosidae). Journal of Arachnology 28:29-42.

Bertani, R.; Nagahama, R. H. \& Fukushima, C. S. 2012. Vitalius nondescriptus comb. nov. (Araneae: Theraphosidae: Theraphosinae): an example of theraphosid taxonomic chaos. Zoologia 29(5):467-473.

Brignoli, P. M. 1983. A catalogue of the Araneae described between 1940 and 1981. Manchester, University Press. 755p.

Cabrera, A. L. 1976. Regiones Fitogeográficas Argentinas. Enciclopedia Argentina de Agricultura y Jardinería, Tomo II, Fascículo I. Buenos Aires, Editorial ACME SACI. 85p.

Cabrera, A. L. \& Willink, A. 1980. Biogeografía de América Latina. 2ed. Serie de Biología. Monografía ${ }^{\circ} 13$. Secretaría General de 
la Organización de los Estados Americanos. Washington D.C., Programa Regional de Desarrollo Científico y Tecnológico. 122p.

CAPOCARIACCO, L. 1955. Estudios sobre los arácnidos de Venezuela. $2^{a}$ parte: Araneae. Acta Biológica Venezuelica 1:265-448.

COOKe, J. A. L.; Roth, V. D. \& Miller, F. H. 1972. The urticating hairs of theraphosid spiders. American Museum Novitates 2498:1-43.

Fukushima, C. S.; Bertani, R. \& Da Silva Jr., P. I. 2005. Revision of Cyriocosmus Simon, 1903, with notes on the genus Hapalopus Ausserer, 1875 (Araneae: Theraphosidae). Zootaxa 846:1-31.

Fukushima, C. S.; Nagahama, R. H. \& Bertani, R. 2008. The identity of Mygale brunnipes C.L. Koch 1842 (Araneae, Theraphosidae), with a redescription of the species and the description of a new genus. The Journal of Arachnology 36:402-406.

GimÉnez, A. M. \& Moglia, J. G. 2003. Arboles del Chaco Argentino. Guía para el reconocimiento dendrológico. Santiago del Estero, Facultad de Ciencias Forestales, UNSE y Secretaría de Ambiente y Desarrollo Sustentable del Ministerio de Desarrollo Social, Editorial El Liberal. 310p.

ICZN - InTERnational COMmission ON ZoOlogical Nomenclature. 1999. International code of zoological nomenclature. 4ed. London, ICZN. 306p.

Koch, C. L. 1850. Übersicht des Arachnidensystems. Nürnberg, Heft $5.77 \mathrm{p}$

Mello-Leitão, C. F. DE. 1923a. Aracnídeos da Ilha dos Alcatrazes. Revista do Museu Paulista 13:515-520.

1923b. Theraphosideas do Brasil. Revista do Museu Paulista 13:1-438.

1926. Algumas theraphosoideas novas no Brasil. Revista do Museu Paulista 14:307-325.

Miglio, L. T.; Bonaldo, A. B. \& Pérez-Miles, F. 2013. On Munduruku, a new theraphosid genus from Oriental Amazonia (Araneae, Mygalomorphae). Iheringia, Série Zoologia 103(2):185-189.

Morrone, J. J. 2006. Biogeographic areas and transition zones of Latin America and the Caribbean islands based on panbiogeographic and cladistic analyses of the entomofauna. Annual Review of Entomology 51:467-494.

Naumann, M. 2006. Atlas del Gran Chaco Sudamericano. Buenos Aires, Sociedad Alemana de Cooperación Técnica (GTZ), ErreGé \& Asoc. 92p.

Pérez-Miles, F.; Lucas, S. M.; Silva, P. Da \& Bertani, R. 1996. Systematic revision and cladistic analysis of Theraphosinae (Araneae: Theraphosidae). Mygalomorph 1:33-62.
Petrunkevitch, A. 1911. A synonymic index-catalogue of spiders of North, Central and South America with all adjacent islands, Greenland, Bermuda, West Indies, Terra del Fuego, Galapagos, etc. Bulletin of the American Museum of Natural History 29:1791.

1925. Arachnida from Panama. Transactions of the Connecticut Academy of Arts and Science 27:51-248.

PIZA, S. DE T. 1976. Uma nova aranha migalomorfa do Brasil (Theraphosidae). Revista de Agricultura 51:3-4.

Platnick, N. I. 2013. The world spider catalog, version 14.0 American Museum of Natural History. Available at: <http:// research.amnh. org/iz/spiders/catalog $>$. Accessed on: 2.8.2013.

Pocock, R. I. 1901. Some new and old genera of South American Avicularidae. Annals and Magazine of Natural History 7(8):540-555.

Prado, D. E. 2000. Seasonally dry forests of tropical South America: from forgotten ecosystems to a new phytogeographic unit. Edinburgh Journal of Botany 57:437-461.

Raven, R. 1990. A revision of the Australian spider genus Trittame Koch (Mygalomorphae: Barychelidae) and a new related genus. Invertebrate Taxonomy 4:21-54

Roewer, C. F. 1942. Katalog der Araneae von 1758 bis 1940. Bremen 1:1-1040

Schiapelli, R. D. \& Gerschman DE P., B. S. 1942. Arañas argentinas (parte I). Revista del Museo Argentino de Ciencias Naturales 40:317-332.

SimON, E. 1889. Arachnides. In: Voyage de M. E. Simon au Venezuela (décembre 1887-avril 1888). 4e Mémoire. Annales de la Société Entomologique de France 6(9):169-220.

1897. Liste de arachides recueillis auxîles du Cap Vert, dans la République Argentine et le Paraguay et descriptions d'espèces nouvelles. In Viaggio del Dott. A. Borelli nella République Argentina e nel Paraguay. Bolletino dei Musei di Zoologia ed Anatomia Comparada della Realle Universitá di Torino 12(270):1-8.

Yamamoto, F. U.; Lucas, S. M.; Guadanucci, J. P. L. \& IndicatTi, R. P. 2007. Revision of genus Tmesiphantes Simon (Araneae, Mygalomorphae, Theraphosidae). Revista Brasileira de Zoologia 24(4):971-980.

Yamamoto, F. U.; Lucas, S. M. \& Brescovit, A. D. 2012. Catanduba a new Theraphosinae spider genus from Central Brazil (Araneae, Theraphosidae). Zootaxa 3172:1-19. 